\title{
Use of essential oil on digestive health and blood parameters of maintenance horses
}

[Uso de óleo essencial na saúde digestiva e nos parâmetros sanguíneos de cavalos em manutenção]

\author{
G.V. Pombo, Y.S. Pereira, I.V.F. Gonzaga, F.M.P. Taran, H.C. Mazzo, \\ R. Françoso, T.N. Centini, A.A.O. Gobesso
}

Escola de Medicina Veterinária e Zootecnia - Universidade de São Paulo - Pirassununga, SP

\begin{abstract}
Essential oils (EO) such as carvacrol represent a wide range of mainly volatile aromatic plant compounds which hold antioxidant, antibacterial and antifungal potential, in addition to other properties of interest to animal health, such as the ability to modulate the microbiome. Current horse care commonly involves an intensive management system with an excessive use of concentrated feed, which can lead to severe digestive and metabolic disorders. Studies with EO in horses are limited, but the use of carvacrol essential oil (CEO) can promote benefits in microbial fermentation. The objective was to investigate the effect of different quantities of CEO on the apparent total digestibility of nutrients, microbial profile in the feces and postprandial blood glucose and insulin response when added to the equine diet. Eight Mini-Horse geldings were used (42 \pm 6 months; $135 \pm 15 \mathrm{~kg} \mathrm{BW}$ ) and fed with a proportion of $60 \%$ concentrate and $40 \%$ grass hay. The treatments were: $0,100,200$ and $300 \mathrm{ppm}$ of CEO. The addition of CEO up to $300 \mathrm{ppm}$ did not influence the apparent digestibility of nutrients or the postprandial plasma glucose and insulin response. The use of CEO maintained the fermentative digestive health of horses fed with concentrate diets.
\end{abstract}

Keywords: antimicrobial, carvacrol, fermentation, nutraceutical

\section{RESUMO}

Os óleos essenciais (EO), como o carvacrol, são descritos por representarem ampla gama de compostos principalmente voláteis de plantas aromáticas, com potencial antioxidante, antibacteriano, antifúngico, entre outras propriedades de interesse para a saúde animal, como a modulação do microbioma. Atualmente, os cavalos são submetidos a manejo intensivo, com uso excessivo de ração concentrada, o que pode causar graves distúrbios digestivos e metabólicos. Em cavalos, estudos com EO são limitados, mas o uso de óleo essencial de carvacrol (CEO) poderia promover benefícios na fermentação microbiana. $O$ objetivo da presente pesquisa foi investigar o efeito de diferentes quantidades de óleo essencial de carvacrol, adicionadas à dieta de equinos, sobre a digestibilidade aparente total de nutrientes, o perfil microbiano por meio das fezes e a resposta sanguínea pós-prandial de glicose e insulina. Foram utilizados oito cavalos castrados, da raça Mini-Horse (42 \pm 6 meses), $135 \pm 15 \mathrm{~kg} P \mathrm{~V}$, alimentados na proporção de $60 \%$ concentrado e 40\% feno de capim. Os tratamentos foram: 0, 100, 200 e 300ppm de CEO. A adição de CEO até 300ppm não influencia a digestibilidade aparente dos nutrientes e a resposta de glicose e insulina plasmática pós-prandial. $O$ uso de EO demonstra manter a saúde digestiva fermentativa quando os cavalos são alimentados com dieta rica em concentrado.

Palavras-chave: antimicrobiano, carvacrol, fermentação, nutracêutico

\section{INTRODUCTION}

Since domestication, horses have been subjected to management situations which promote an increased vulnerability to gastrointestinal disorders, leading to consequent systemic repercussions such as colic and laminitis, and other clinical conditions which have high rates of morbidity and mortality (Proudman et al., 2015). Changes occurring the digestive tract are among the main conditions that affect horses and are often related to diet, stress conditions and the use

Recebido em 20 de abril de 2020

Aceito em 22 de setembro de 2020

E-mail: gabriela.guarnieri@unifeb.edu.br 
of anti-inflammatory or antimicrobials which can negatively impact the intestinal microbiota (Harlow et al., 2013; Perkins et al., 2012). Currently, one of the main factors responsible for negative gastrointestinal changes in horses is due to the use of large amounts of concentrate and high starch content in the equine diet. Depending on the source, the supply of starch above $2 \mathrm{~g} / \mathrm{kg}$ of body weight per meal in the equine diet may exceed the capacity of enzymatic digestion in the small intestine, increasing the amount of rapidly fermentable carbohydrates in the colon and cecum, and can result in metabolic complications (Julliand et al., 2006; Kienzle, 1994).

In horses, excess starch in the diet has been linked to causing decreases to $\mathrm{pH}$, altering the production of short chain fatty acids, favoring opportunistic microorganisms (such as some species of gramnegative bacteria), in addition to compromising the immune system (Bland, 2016). To benefit certain animal species, essential oils from plants have been studied as a modulator of the microbiota (Franz et al., 2010). Essential oils (EO) are secondary metabolites of plants, constituents or aromatic essences, widely used in the cosmetics, perfumery and aromatherapy industries. However, knowledge of their beneficial biological properties, including their antimicrobial, antifungal, anti-inflammatory, antioxidant potential, has been generating interest in studies involving human and animal health (Dhifi et al., 2016).

In general, essential oils are a complex mixture of alcohols, aldehydes, hydrocarbons, ketones, esters and ethers (Benchaar et al., 2007), with the highest concentration of terpenes and terpenoids and to a lesser extent, phenylpropanoids found in all living plant tissues, which are concentrated in the bark, flowers, leaves, rhizomes and seeds (Dhifi et al., 2016). One of the relevant actions of EO to animal production is its antimicrobial activity, mainly related to its ability to interact with various binding sites on the bacterial cell membrane and not specifically a mode of action, being more potent in relation to gram-positive bacteria (Burt, 2004; Kissels et al., 2017).

In horses, studies investigating the action of essential oils are limited, although the equine microbiome in the large intestine, composed of bacteria, fungi, protozoa, bacteriophages, and archaea (Kauter et al., 2019), is similar to those found in the fermentation compartment of ruminants (Cobellis et al., 2016). Essential oils are described as representing a wide range of mainly volatile compounds with the potential to manipulate the rumen microbial population and the fermentation profile (Calsamiglia et al., 2007; Cobellis et al., 2016). It has been shown that EO can reduce the rumen acetate-to-propionate ratio, amino acid deamination and methanogenesis (Benchaar et al., 2008; Klevenhusen et al., 2012). Most importantly, unlike dietary antibiotics (e.g. ionophores), EO do not alter the activities of ruminal microbes towards a specific mode of action and therefore have more potent mechanisms of action that are less likely to lose their effectiveness with time (Kissels et al., 2017).

One essential oil compound that is known for its strong antimicrobial action is carvacrol, monoterpenic phenol, produced by an abundant number of aromatic plants, including thyme and oregano. Due to the presence of a hydroxyl group in its structure, carvacrol mainly causes changes in the composition of fatty acids in the cell membrane, increasing the permeability of the cytoplasmic membrane to ATP, and/or cell lysis (Benchaar; Greathead, 2011; Burt, 2004; Lambert et al., 2001). EO exhibit antimicrobial effects against a wide range of microbial species including Aspergillus, Fusarium, Bacillus, Salmonella, Listeria, Streptococci, Pseudomonas and various others, as well as in both grampositive and gram-negative bacteria, and in aerobic and anaerobic bacteria (Bagamboula et al., 2003; Benchaar, Greathead, 2011; Lambert et al., 2001; Suganthi, Manpal, 2013). However, the positive effects greatly depend on the bacterial cell structure and their susceptibility to essential oil as well as the dosage used (Benchaar et al., 2008; Pauli, Schilcher, 2010), which may vary according to the animal species.

The aim of this study was to investigate the effect of different quantities of carvacrol essential oil when added to the equine diet, on the total apparent digestibility of nutrients and microbial profile of Fibrobacter succinogenes, Ruminococcus flavefaciens, and Lactobacillus genus, as determined by fecal and postprandial blood glucose and insulin examinations. 


\section{MATERIAL AND METHODS}

The experiment was carried out in Pirassununga (SP), Brazil, Latitude $21^{\circ} 36^{\prime} 00$ "S; Longitude: $47^{\circ} 18^{\prime} 00^{\prime \prime} \mathrm{W}$. Eight gelding Mini-Horses (42 \pm 6 months) with an average BW of $135 \pm 15 \mathrm{~kg}$ were used. Animals were individually housed in box stalls, bedded with wood shavings and left for 2 $\mathrm{h} /$ day on a sand paddock, except during the sample collection period. Water and mineral salt were provided ad libitum. The study was conducted under the license from the 'Ethics Committee for Animal use' (CEUA/FMVZ-USP No.2453/2011).

The horses were distributed in randomized Latin square design 4 x 4 (4 different amount of essential oil and 4 phases). Horses were fed individually at $2 \%$ of $\mathrm{BW}$ on a DM basis in a ratio of 60:40 concentrate: hay (Cynodon sp. cv.
Tifton-85). The chemical composition of the diet is shown in Table 1. Treatments were composed of the different quantities of carvacrol essential oil (CEO) as follows: 0 (control), 100, 200 and 300 ppm, using a concentration of $7 \%$ CEO. Due to a lack of prior data in the literature for use in horses, the amounts used were the same as those studied by Ilsley et al. (2003) and Oetting et al. (2006) with piglets and lactating sows, respectively, owing to the pre-caecal digestive characteristic of a monogastric and the related non-toxic effects. Concentrate was supplied twice a day, in the morning (07h00) and at the end of the day (19h00). The various quantities of essential oil (100, 200 and $300 \mathrm{ppm})$ were diluted in $5 \mathrm{~g}$ of corn flour (milled at $1 \mathrm{~mm}$ ) using a mixer type "V" Marconi ${ }^{\circledR}$ model MA200 and divided into individual doses. The amount corresponding to each treatment was top-dressed onto the concentrate.

Table 1. Chemical composition of the hay and concentrate used in the diet based on the dry matter $(\%)$

\begin{tabular}{lcc}
\multicolumn{1}{c}{ Nutrients } & Hay & Concentrate \\
\hline Dry Matter (DM) & 91.15 & 89.80 \\
Crude Protein (CP) & 7.12 & 17.45 \\
Ether Extract (EE) & 1.11 & 5.45 \\
Mineral Matter (MM) & 5.31 & 6.59 \\
Calcium (Ca) & 0.49 & 1.12 \\
Phosphorus (P) & 0.22 & 0.69 \\
Neutral Detergent Fiber (NDF) & 70.52 & 31.38 \\
Acid Detergent Fiber (ADF) & 35.70 & 16.24 \\
Starch & 1.24 & 24.25 \\
\hline
\end{tabular}

Each experiment consisted of four periods of 23 days: 15 adaptation days and 5 days for data collection, with a 3-day-wash-out interval between periods (Gobert et al., 2006). Apparent total tract digestibility (ATTD) of nutrients was estimated by the total fecal collection method whereby animals were kept in pens with concrete floors and no bedding. Feces were collected every $24 \mathrm{~h}$ and placed in plastic bags, weighed and identified by animal. After the data collection period, the total feces excreted per animal was homogenized and $10 \%$ was removed, wrapped in plastic bags and frozen at $20^{\circ} \mathrm{C}$ for further bromatological analysis. Hay, concentrate and fecal samples were analyzed for dry matter (DM), organic matter (OM) and crude protein (CP) content (micro-Kjeldahl, $\mathrm{N}$ x 6.25) as well as for ether extract (EEd) (AOAC, 2000) and neutral detergent fiber (NDF) and acid detergent fiber (ADF) according to Van Soest et al. (1991). Apparent total tract digestibility of nutrients was calculated by the following formula: ATTD $(\%)=(($ intake of nutrients $(\mathrm{g})$ - nutrients in feces $(\mathrm{g})) /$ intake of nutrients $(\mathrm{g})) \times 100$.

For the measurement of glucose in the plasma and insulin in the serum, blood was collected by jugular vein puncture in vacuum tubes (Vacutainer BD®) 30 minutes before, 30min, $90 \mathrm{~min}, 150 \mathrm{~min}$ and $210 \mathrm{~min}$ after the diet supply for further analysis. Plasma glucose was collected in Vacutainer BD® Sodium Fluoride tubes, and serum insulin was collected in Vacutainer BD® tubes without anticoagulants (Oliveira Ramalho et al., 2012; Stull, Rodiek, 1988). The samples were kept at rest in a temperature-controlled environment $\left(18^{\circ} \mathrm{C}\right)$ for approximately 20 minutes and then centrifuged for 10 minutes at 4,000 rpm (Centribio model 80-2B-15ML centrifuge; $1.800 \mathrm{xg})$. After this procedure, the supernatant was transferred to properly labeled $1.5 \mathrm{~mL}$ plastic microtubes and kept in freezers at $-20^{\circ} \mathrm{C}$ (Stull, 
Rodiek, 1988), which were later sent to a private laboratory for analysis. Insulin concentration was measured by chemiluminescence using Access Ultrasensitive Insulin Reagent Kit (Beckman Coulter, ref: 33410), while glucose was measured by colorimetric enzymatic testing using the Enzyme Glucose Kit (LIFE Biotechnology, ref: 100/410).

For microbial analysis, approximately $20 \mathrm{~g}$ of fresh feces was collected at the end of the fifth day data collection period, placed into sterile falcon tubes and immediately frozen at $-80^{\circ} \mathrm{C}$ until analysis. Samples were submitted to DNA extraction. Total cellular DNA was extracted from $0.2 \mathrm{~g}$ samples using the QIAamp DNA Stool Mini Kit (QIAamps® DNA Stool Handbook, 2012) and the genetic profile of each species were systematically checked using the real-time PCR method (qPCR) and specific primers. The specific primers used were for Fibrobacter succinogenes (F:5'-GGTATGGGATGAGCTTGC-3', R:5'GCCTGCCCCTGAACTATC-3'), Lactobacillus genus (F:5'-AGCAGTAGGGAATCTTCCA-3', R:5'-CA CCGCTACACATGGAG-3') and Ruminococcus flavefaciens (F:5'TCTGGAAACGGATGGTA-3', R:5'CCTTTAAGACAGGAGTTTACAA-3'). Total bacteria population was quantified with the primer (F:5'- GTGSTGCAYGGYTGTCGTCA3', 5'-ACGTCRTCCMCACCTTCTC-3') (Maeda et al., 2003) and their relative populations of search bacteria were calculated using the $2^{-\Delta \Delta C} T$ method (Livak and Schmittgen, 2001).
The statistical model adopted for the analyzed variables was:

$$
\begin{gathered}
Y_{i j k l}=\mu+\frac{a_{i}}{q_{k}}+\frac{p_{j}}{q_{k}}+q_{k}+\text { trat }_{\cdot l} \\
+e_{i j k l}
\end{gathered}
$$

Where: $Y i j k l=$ observation of animal, $i=$ in $\operatorname{period} j$, in square $k$, receiving the treatment $l ; \mu=$ overall mean; $a i / q k=$ effect of animal $i$ within square $k$; $p j / q k=$ effect of period $i$ within square $k ; q k=$ square effect $k$; trat $l=$ effect of treatment $l$; eijkl=random error. The results of digestibility, glucose, insulin and bacterial were submitted to analysis of variance with repeated measures and polynomial regression by the PROC MIXED procedure of SAS (Statistical Analysis System, version 9.1), having previously verified the normality of the residues by the Shapiro-Wilk test (Proc Univariate) and homogeneity of variance by the $\mathrm{F}$ test. means were compared by the Tukey Test $(\mathrm{P}<0.05)$, with fixed effects for treatment, time, interaction treatment $\mathrm{x}$ time and the random effects of animal and period.

\section{RESULTS AND DISCUSSION}

The apparent total tract digestibility (ATTD) of DM, OM, CP, EE, MM, NDF and ADF for each CEO treatment are described in Table 2. There was no observed difference between CEO treatments on the values of the total apparent digestibility coefficient of nutrients.

Table 2. Mean and standard error of the mean (SEM) of the apparent total tract digestibility (ATTD, \%) for the treatments $0,100,200$ and 300 ppm of carvacrol essential oil per day in the horse diets

\begin{tabular}{|c|c|c|c|c|c|c|c|c|}
\hline \multirow[t]{2}{*}{$\operatorname{ATTD}(\%)$} & \multicolumn{4}{|c|}{$\begin{array}{l}\text { Carvacrol essential oil treatment } \\
(\mathrm{ppm})\end{array}$} & \multirow[t]{2}{*}{ SEM } & \multicolumn{3}{|c|}{ P Value* } \\
\hline & 0 & 100 & 200 & 300 & & Treatment & Linear & Quad $^{1}$ \\
\hline Dry matter & 63.78 & 65.80 & 64.28 & 63.68 & 0.66 & 0.48 & 0.70 & 0.23 \\
\hline Organic Matter & 66.26 & 67.82 & 66.96 & 66.45 & 0.62 & 0.66 & 0.94 & 0.29 \\
\hline Crude Protein & 75.41 & 74.82 & 74.97 & 74.48 & 0.57 & 0.58 & 0.31 & 0.37 \\
\hline Ether extract & 75.79 & 71.85 & 71.39 & 73.69 & 1.54 & 0.64 & 0.58 & 0.25 \\
\hline Mineral matter & 25.54 & 27.62 & 25.92 & 23.85 & 0.99 & 0.55 & 0.42 & 0.27 \\
\hline Neutral detergent fiber & 46.12 & 50.08 & 47.22 & 46.10 & 1.28 & 0.58 & 0.78 & 0.28 \\
\hline Acid detergent fiber & 44.62 & 49.77 & 45.59 & 43.58 & 1.48 & 0.46 & 0.57 & 0.22 \\
\hline
\end{tabular}

* Level of significance: $\mathrm{P}<0.05 .{ }^{1}$ Quadratic Effect

Studies using essential oils in horses are scarce. Some authors have already made use of EO in other species. This research corroborates with Tekippe et al. (2011), where $5.7 \mathrm{~g} /$ day of CEO was added to the diet of lactating cows and no effect was observed on the apparent digestibility of DM and OM, with values of $63 \%$ and $64 \%$, respectively. Similarly, Soltan et al. (2018) did not observe any effect on the apparent digestibility of dry and organic matter when a 
mixture of essential oils with 200 and $400 \mathrm{mg}$ of carvacrol and a microencapsulated blend of essential oil was administered to sheep.

The plasma glucose and serum insulin values are described in Table 3. The plasmatic glucose concentrations after food intake showed no significant interaction between treatment $\mathrm{x}$ time $(\mathrm{P}<0.05)$. There was a difference in plasmatic glucose concentrations between the times for each treatment. The values of treatments 0,100 and 300 ppm of CEO increased mainly 90 minutes post diet supply, reaching the glycemic peak at up to
$150 \mathrm{~min}$ and starting the decline from 210min. The only treatment which did not show a significant difference between times was at the amount of $200 \mathrm{ppm}$ which maintained a stable curve. This did not however, differ from the other treatments at each time. The observed glycemic response values are in accordance with the reference parameters ranging from 75-115 mg/dL (Meyer, Hage, 1995), where blood glucose ranges from 80 to $100 \mathrm{mg} / \mathrm{dL}$ at fasting, rising to $150 \mathrm{mg} / \mathrm{dL}$ between 2-3 hours after meals which are rich in starch.

Table 3. Mean and standard error of the mean (SEM) for plasmatic glucose concentration (mg/dL) and insulin concentration ( $\mu \mathrm{U} / \mathrm{dL})$ according to the treatments $0,100,200$ and $300 \mathrm{ppm}$ of carvacrol essential oil at $-30,30,90,150$ and $210 \mathrm{~min}$

\begin{tabular}{lccccc}
\hline \multirow{2}{*}{ Treatment } & \multicolumn{5}{c}{ Plasmatic glucose concentration $(\mathrm{mg} / \mathrm{dL})$} \\
\cline { 2 - 6 } & -30 & 30 & 90 & 150 & 210 \\
\hline 0 & $85.82 \pm 8.2^{\mathrm{bA}}$ & $98.61 \pm 10.3^{\mathrm{abA}}$ & $124.23 \pm 18.9^{\mathrm{aA}}$ & $125.54 \pm 23.9^{\mathrm{aA}}$ & $108.73 \pm 20.4^{\mathrm{abA}}$ \\
100 & $85.11 \pm 8.1^{\mathrm{bA}}$ & $99.94 \pm 10.4^{\mathrm{abA}}$ & $112.91 \pm 17.7^{\mathrm{abA}}$ & $122.02 \pm 22.0^{\mathrm{aA}}$ & $119.47 \pm 20.2^{\mathrm{abA}}$ \\
200 & $85.77 \pm 8.1^{\mathrm{aA}}$ & $98.43 \pm 10.4^{\mathrm{aA}}$ & $107.25 \pm 17.8^{\mathrm{aA}}$ & $114.19 \pm 22.1^{\mathrm{aA}}$ & $114.04 \pm 20.1^{\mathrm{aA}}$ \\
300 & $85.80 \pm 8.0^{\mathrm{bA}}$ & $100.71 \pm 10.1^{\mathrm{abA}}$ & $121.36 \pm 16.4^{\mathrm{aA}}$ & $118.74 \pm 20.8^{\mathrm{abA}}$ & $104.55 \pm 19.3^{\mathrm{abA}}$ \\
\hline \multicolumn{5}{c}{ Plasmatic insulin concentration $(\mu \mathrm{U} / \mathrm{dL})$} \\
\hline 0 & $5.10 \pm 1.45^{\mathrm{dA}}$ & $15.10 \pm 8.49^{\mathrm{cA}}$ & $55.72 \pm 53.7^{\mathrm{bA}}$ & $72.72 \pm 59.6^{\mathrm{aA}}$ & $58.22 \pm 47.0^{\mathrm{bB}}$ \\
100 & $4.50 \pm 1.92^{\mathrm{eA}}$ & $13.37 \pm 7.44^{\mathrm{dA}}$ & $30.87 \pm 31.1^{\mathrm{cB}}$ & $59.12 \pm 71.1^{\mathrm{bB}}$ & $70.80 \pm 92.5^{\mathrm{aA}}$ \\
200 & $3.89 \pm 2.53^{\mathrm{dA}}$ & $14.02 \pm 8.58^{\mathrm{cA}}$ & $43.27 \pm 51.3^{\mathrm{bAB}}$ & $57.52 \pm 63.9^{\mathrm{aB}}$ & $63.27 \pm 71.3^{\mathrm{aAB}}$ \\
300 & $4.50 \pm 1.19^{\mathrm{dA}}$ & $16.75 \pm 10.3^{\mathrm{cA}}$ & $59.87 \pm 61.5^{\mathrm{bA}}$ & $77.25 \pm 90.8^{\mathrm{aA}}$ & $70.87 \pm 77.4^{\mathrm{aA}}$ \\
\hline
\end{tabular}

a, $b$ Means within a row with different superscript letters differ, $\mathrm{P}<0.05$ by Tukey test. A, B Means within a column with different superscript letters differ, $\mathrm{P}<0.05$ by Tukey test.

The serum insulin concentrations showed a treatment effect at 90, 150 and 210min $(\mathrm{P}<0.05)$. In relation to the other treatments, $\mathrm{CEO}$ treatments of 0 and $300 \mathrm{ppm}$ had the highest insulin values observed at 90 and 150 minutes after diet supply, with the peak occurring at 150 minutes, while treatments 100 and $200 \mathrm{ppm}$ displayed the highest insulin values at 210 minutes post diet supply. Fasting insulin concentrations are generally between 5 and $20 \mu \mathrm{UI} / \mathrm{mL}$; Insulin is secreted as blood glucose concentrations increase, serving to improve cell absorption and lipogenesis (Argenzio; Hintz, 1972). The glycemic and insulinemic responses of horses have been related to diet type by evaluating the influence of different grain processing techniques and different amounts of starch added to the diet (Wilcox, 2005). With increased starch in the diet, peaks of plasmatic insulin can even triple in comparison to values prior to food intake, and the peak time is inversely proportional to the amount of starch ingested.
A greater amount of starch (e.g. hay: concentrate diet relation is up to 40:60) can also increase glycemia, stimulating the pancreas to secret insulin, and therefore higher levels of glucose directly stimulate insulinemia. However, there is little information about the influence of essential oils on these parameters. The values of insulin in this study were similar to the study by Taran et al. (2016), which evaluated the plasmatic insulin response with a high ratio of concentrate: roughage (70:30) in Mini-Horses.

In this sense, Vervuert et al. (2009), observed that 30 to 45 minutes after feeding there was a significant increase in glucose and plasma insulin for all test diets, decreasing to baseline values between 150 to 240 minutes. Depew et al. (1994) observed an increase in plasma concentration glucose 1 hour after feeding, and insulin 2 hours post feeding. On the other hand, Witham and Stull (1998), reported that the peak of plasma glucose 
was obtained from 2 to 3 hours, and insulin between 3 to 4 hours after consuming food in the morning. In the present study, after 210 minutes only the control treatment started the decline curve of insulin. In relation to microbial profile, no treatment effect was observed for the different inclusion levels of CEO on the quantification for Fibrobacter succionogenes and Lactobacillus spp $(\mathrm{P}<0.05)$. However, a quadratic effect was observed for the quantification of Ruminococcus flavefaciens $(\mathrm{P}=0.05)$ (Figure 1).

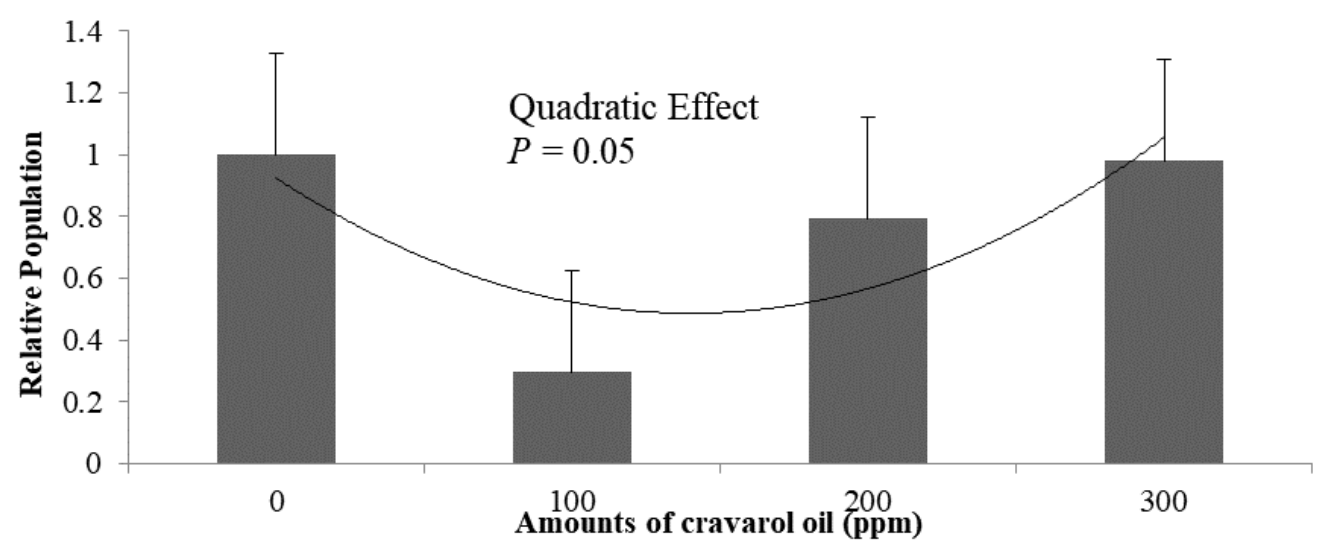

Figure 1. Population of Ruminococcus flavefaciens for the different treatments 0, 100, 200 and 300 ppm of carvacrol essential oil.

Julliand and Grimm (2016) describe the cellulolytic bacteria $R$. flavefaciens and $R$. albus, as well as $F$. succinogenes as relevant groups of the central microbiome throughout the equine large intestine, playing an essential role in the life of this animal through the use of the plant cell wall, where its reduction directly interferes with the proper functioning of the fermentation environment. According to Soltan et al. (2018) encapsulated essential oils appear to somehow have a selective influence against certain microbial growth, while promoting the growth of other types of microorganisms over time. This may be a probable mechanism for the antimicrobial and antioxidant actions of the combination of phenylpropanes fraction, including cinnamaldehyde and eugenol, and the terpenes fraction containing carvacrol. In this sense, by increasing the concentration of the essential oil complex an improvement was observed on the development of the fibrolytic specific group of bacteria, avoiding the negative impact of high concentrate diets.

In horses, diets containing starch sources with a high proportion of amylopectin (greater than 2 $\mathrm{g} / \mathrm{kg}$ of body weight per meal) can exceed the capacity of the small intestine to digest the starch and reach the large intestine, thus disturbing its microbial balance (Julliand; de Fombelle;
Varloud, 2006; Kienzle, 1994). When fed a highstarch diet compared to a high-fiber diet, Medina et al. (2002) observed an increase in the concentration of lactic acid bacteria and lactate, a decrease in $\mathrm{pH}$ and a subsequent reduction in the cellulolytic bacteria development in horses. Therefore, in this study, the daily intake of starch was $2.65 \mathrm{~g} / \mathrm{kg}$ of body weight per meal, and no metabolic disorders were observed. We believe that regardless of the quantity, the use of carvacrol maintained the health of the gastrointestinal tract, preventing disorders related to increased starch intake.

\section{CONCLUSION}

The addition of carvacrol essential oil to horses up to $300 \mathrm{ppm}$ does not influence the apparent digestibility of nutrients and the response of postprandial plasmatic glucose and insulin. The addition of carvacrol essential oil maintained the fermentative digestive health of horses fed with high concentrate diets.

\section{ACKNOWLEDGEMENTS}

The authors' acknowledge the financial support by 'Fundação de Amparo à Pesquisa do Estado de São Paulo/FAPESP, under protocol de $\mathrm{N}^{\circ}$. 2012/04161-6'. 


\section{REFERENCES}

ARGENZIO, R.A.; HINTZ, H.F. Effect of diet on glucose entry and oxidation rates in ponies. $J$. Nutr., v.102, p.879-892, 1972.

BAGAMBOULA, C.F.; UYTTENDAELE, M.; DEBEVERE, J. Antimicrobial effect of spices and herbs on Shigella sonnei and Shigella flexneri. J. Food Protec., v.66, p.668-673, 2003.

BENCHAAR, C.; CHAVES, A.V.; FRASER, C.R. et al. Effects of essential oils and their components on in vitro rumen microbial fermentation. Can. J. Anim. Sci., v.87, p.413-419, 2007.

BENCHAAR, C.; CALSAMIGLIA, S.; CHAVES, A.V. et al. A review of plant-derived essential oils in ruminant nutrition and production. Anim. Feed Sci. Technol., v.145, p.209-228, 2008.

BENCHAAR, C.; GREATHEAD, H. Essential oils and opportunities to mitigate enteric methane emissions from ruminants. Anim. Feed Sci. Technol., v.166-167, p.338-355, 2011.

BLAND, S.D. Equine colic: a review of the equine hindgut and colic. Vet. Sci. Devel., v.6, n.1, 2016.

BURT, S. Essential oils: their antibacterial properties and potential applications in foods - a review. 2004. Available in: https://doi.org/10.1016/j.ijfoodmicro.2004.03.02 2. Accessed in: 15 Aug. 2020.

CALSAMIGLIA, S.; BUSQUET, M.; CARDOZO, P.W.; CASTILLEJOS, L.; FERRET, A. Invited review: essential oils as modifiers of rumen microbial fermentation. 2007. Available in: https://doi.org/10.3168/jds.2006644. Accessed in: 15 Aug. 2020.

COBELLIS, G.; TRABALZA-MARINUCCI, M.; YU, Z. Critical evaluation of essential oils as rumen modifiers in ruminant nutrition: a review. 2016. Available in https://doi.org/10.1016/j.scitotenv.2015.12.103. Accessed in: 15 Aug. 2020.
DEPEW, C.L.; THOMPSON JR, D.L.; FERNANDEZ, L.M.; STICKER, L.S.; BURLEIGH, D.W. Changes in concentrations of hormones, metabolites, and amino acids in plasma of adult horses relative to overnight feed deprivation followed by a pellet-hay meal fed at noon. J. Anim. Sci., v.72, p.1530-1539, 1994.

DHIFI, W.; BELLILI, S.; JAZI, S.; BAHLOUL, N.; MNIF, W. Essential Oils' chemical characterization and investigation of some biological activities: a critical review. Medicines, v.3, p.25, 2016.

FRANZ, C.; BASER, K. H.C.; WINDISCH, W. Essential oils and aromatic plants in animal feeding - a European perspective. A review. 2010. Available in: https://doi.org/10.1002/ffj.1967. Accessed in: February2, 2020

GOBERT, J. et al. Digestive fate of Saccharomyces cerevisiae CBS 493.94, fed at three different concentrations to horses. Reprod. Nutr. Dev., v.46, p.S95, 2006.

HARLOW, B.E.; LAWRENCE, L.M.; FLYTHE, M.D. Diarrhea-associated pathogens, lactobacilli and cellulolytic bacteria in equine feces: Responses to antibiotic challenge. Vet. Microbiol., v.166, p.225-232, 2013.

ILSLEY, S.E. et al. Plant extracts as supplements for lactating sows: effects on piglet performance, sow food intake and diet digestibility. Anim. Sci., v.77, p.247-254, 2003.

JULLIAND, V.; DE FOMBELLE, A.; VARLOUD, M. Starch digestion in horses: the impact of feed processing. Livest. Sci., v.100, p.44-52, 2006.

JULLIAND, V.; GRIMM, P. Horse species symposium: the microbiome of the horse hindgut: history and current knowledge. 2016. Available in: $\quad$ https://doi.org/10.2527/jas.2015-0198. Accessed in: 15 Aug. 2020.

KAUTER, A.; EPPING, L.; SEMMLER, T. et al. The gut microbiome of horses: current research on equine enteral microbiota and future perspectives. Anim. Microbiome, v.1, 2019. Available in: https://doi.org/10.1186/s42523-019-0013-3.

Accessed in: 15 Aug. 2020. 
KIENZLE, E. Small intestinal digestion of starch in the horse. Rev. Méd. Vét., v.145, 1994. Available in: http://agris.fao.org/agrissearch/search.do?recordID=FR9402806.

Accessed in: 15 Aug. 2020.

KISSELS, W.; WU, X.; SANTOS, R.R. Short communication: interaction of the isomers carvacrol and thymol with the antibiotics doxycycline and tilmicosin: In vitro effects against pathogenic bacteria commonly found in the respiratory tract of calves. J. Dairy Sci., v.100, p.970-974, 2017.

KLEVENHUSEN, F.; MURO-REYES, A.; KHIAOSA-ARD, R.; METZLER-ZEBELI, B.U.; ZEBELI, Q. A meta-analysis of effects of chemical composition of incubated diet and bioactive compounds on in vitro ruminal fermentation. Anim. Feed Sci. Technol., v.176, p.61-69, 2012.

LAMBERT, R.J.W.; SKANDAMIS, P.N.; COOTE, P.J.; NYCHAS, G.J. A study of the minimum inhibitory concentration and mode of action of oregano essential oil, thymol and carvacrol. J. Appl. Microbiol., v.91, p.453-462, 2001.

LIVAK, K.J.; SCHMITTGEN, T.D. Analysis of relative gene expression data using real-time quantitative PCR and the 2- $\Delta \Delta \mathrm{CT}$ method. Methods, v.25, p.402-408, 2001.

MAEDA, H.; FUJIMOTO, C.; HARUKI, Y .et al. Quantitative real-time PCR using TaqMan and SYBR Green for Actinobacillus actinomycetemcomitans, Porphyromonas gingivalis, Prevotella intermedia, tetQ gene and total bacteria. FEMS Immunol. Med. Microbiol., v.39, p.81-86, 2003.

MEDINA, B.; GIRAROL,I.; JACOTOT, E.; JULLIAND, V. Effect of a preparation of on microbial profiles and fermentation patterns in the large intestine of horses fed a high fiber or a high starch diet. J. Anim. Sci., v.80, p.2600, 2002.

MEYER, H.; HAGE, S. Alimentação de cavalos. São Paulo: Livraria Varela, 1995. 312p.

OETTING, L.L.; UTIYAMA, C.E.; GIANI, P.A. et al. Effects of herbal extracts and antimicrobials on apparent digestibility, performance, organs morphometry and intestinal histology of weanling pigs. Rev. Bras. Zootec., v.35, p.1389-1397, 2006.
OFFICIAL methods of analysis. Washington: AOAC, 2000.

OLIVEIRA RAMALHO, L.; CAIADO, J.C.C.C.; SOUZA, V.R.C.; COELHO, C.S. Glicemia e concentrações séricas de insulina, triglicérides e cortisol em equinos da raça Quarto de Milha e mestiços usados em provas de laço em dupla. Braz. J. Vet. Res. Anim. Sci., v.49, p.318-324, 2012.

PAULI, A.; SCHILCHER, H. 12 In Vitro antimicrobial activities of essential oils monographed in the European Pharmacopoeia. 6.ed. [s.1.]: Essential, 2010. p.353.

PERKINS, G.A.; DEN BAKKER, H.C.; BURTON, A.J. et al. Equine stomachs harbor an abundant and diverse mucosal microbiota. Appl. Environ. Microbiol., v.78, p.2522-2532, 2012.

PROUDMAN, C.J. HUNTER, J.O.; DARBY, A.C. et al. Characterisation of the faecal metabolome and microbiome of Thoroughbred racehorses. Equine Vet. J., v.47, p.580-586, 2015.

SOLTAN, Y.A.; NATEL, A.S.; ARAUJO, R.C.; MORSY, A.S.; ABDALLA, A.L. Progressive adaptation of sheep to a microencapsulated blend of essential oils: Ruminal fermentation, methane emission, nutrient digestibility, and microbial protein synthesis. Anim. Feed Sci. Technol., v.237, p.8-18, 2018.

STULL, C.L.; RODIEK, A.V. Responses of blood glucose, insulin and cortisol concentrations to common equine diets. J. Nutr., v.118, p.206$213,1988$.

SUGANTHI, R.; MANPAL, S. Biological and pharmacological of actions carvacrol and its effects on poultry: an updated review. World J. Pharm. Pharm. Sci., v.2, p.3581-3595, 2013.

TARAN, F.M.P.; GOBESSO, A.A.O; GONZAGA, I.V.F.; FRANÇOSO, R. et al. Effects of different amounts of Saccharomyces cerevisiae supplementation on apparent digestibility and faecal parameters in horses fed high-roughage and high-concentrate diets. Livest. Sci., v.186, p.29-33, 2016.

TEKIPPE, J.A.; HRISTOV, A.N.; HEYLER, K.S. et al. Rumen fermentation and production effects of Origanum vulgare L. leaves in lactating dairy cows. J. Dairy Sci., v.94, p.5065-5079, 2011. 
VAN SOEST, P.J.; ROBERTSON, J.B.; LEWIS, B.A. Methods for dietary fiber, neutral detergent fiber, and nonstarch polysaccharides in relation to animal nutrition. J. Dairy Sci., v.74, p.3583-3597, 1991.

VERVUERT, I.; VOIGT, K.; HOLLANDS, T. et $a l$. Effect of feeding increasing quantities of starch on glycaemic and insulinaemic responses in healthy horses. Vet. J., v.182, p.67-72, 2009.
WILCOX, G. Insulin and insulin resistance. Clin. Biochem. Rev., v.26, p.19-39, 2005.

WITHAM, C.L.; STULL, C.L. Metabolic responses of chronically starved horses to refeeding with three isoenergetic diets. J. Am. Vet. Med. Assoc., v.212, p.691-696, 1998. 